\title{
What African Languages Tell Us About Accent Typology*
}

\author{
Laura J. Downing
}

ZAS Berlin

The goal of this paper is to survey the accent systems of the indigenous languages of Africa. Although roughly one third of the world's languages are spoken in Africa, this continent has tended to be underrepresented in earlier stress and accent typology surveys, like Hyman (1977). This one aims to fill that gap. Two main contributions to the typology of accent are made by this study of African languages. First, it confirms Hyman's (1977) earlier finding that (stem-)initial and penult are the most common positions, cross-linguistically, to be assigned main stress. Further, it shows that not only stress but also tone and segment distribution can define prominence asymmetries which are best analyzed in terms of accent.

\section{Introduction}

According to Heine \& Nurse (2000), citing the Ethnologue, over 2,000 languages - roughly one-third of the world's languages - are currently spoken in Africa by some 750 million people. (In this paper, no discussion is included of recently introduced European colonial languages, like English, French, Portuguese or Afrikaans.) African languages tend to be underrepresented in surveys of stress and accent systems like Hyman (1977), however, as scholars seeking to make generalizations about accent in African languages must tackle a number of problems. First, one has to confront the sheer number and variety of

\footnotetext{
Many people generously shared their expertise with me as I wrote this paper, providing information and feedback, sharing their own unpublished work and pointing me to the work of others. I would especially like to thank Akin Akinlabi, Lee Bickmore, Simon Donnelly, Knut Felberg, Leoma Gilley, Rob Goedemans, Tom Güldemann, Silke Hamann, John Harris, Omar Ka, Michael Kenstowicz, Will Leben, Brian McHugh, Amanda Miller-Ockhuizen, Paul Newman, David Odden, Bert Remijsen, Sharon Rose, Eno-Abasi Urua and Valentin Vydrine. This paper could not have been written without the research assistance of Sabine Zerbian, who guided me through the Berlin library system and spent many hours helping me locate much of the information surveyed here.
} 
African languages. These 2,000+ languages have been classified into four large families: Niger-Congo (1,436 languages), Afro-Asiatic (371), Nilo-Saharan (196) and Khoisan (35). Further, one member of the Austronesian family, Malagasy, is spoken on the island of Madagascar. As each of the four major families includes a large number of languages further grouped into diverse subfamilies, it can be difficult to make generalizations about accent even within a single subfamily.

Another problem in surveying African accent systems is that, as Heine \& Nurse (2000) point out, most African languages remain poorly documented. Of the four large families, Afro-Asiatic is the best analyzed, as it has the longest history of scholarship carried out by the largest number of scholars. The majority of the languages in the other families are not as well described and analyzed due to the relatively small number of scholars working on an extremely large number of languages for a much shorter period of time. As a result, for most African languages, the only documentation often consists of a grammatical sketch (often many years old using idiosyncratic transcription systems), an analysis of part of the language, or a couple of short journal articles. Accent (along with many other grammatical features) is not always mentioned or reliably described and documented in these sources. As a result, this survey, like all comparative work on African languages, comes with the caveat that the generalizations are based on the information available which might be so limited as to be unrepresentative in some cases.

A final problem in surveying African accent systems arises from both descriptive and theoretical controversies in defining metrical accent. As background to discussing these controversies, it is important to note that the languages of sub-Saharan Africa are overwhelmingly tonal (Welmers 1973). Of the non-tonal languages, many of the best documented - the African Arabic dialects, Berber, North Atlantic (Niger-Congo) languages - uncontroversially have stress accent. Many of the uncontroversially tonal languages, notably many Bantu languages, also uncontroversially have non-tonal stress accent. (All of these stress systems are discussed below.) However, for many African tonal languages, scholars disagree about the role of accent. As Welmers (1973) notes, tone has been notoriously underdescribed for African languages as it is often considered "too hard to hear" by non-native speakers of tone languages. (Most descriptions of African languages have been written by native speakers of IndoEuropean languages rather than by native speakers of the languages themselves.) One easily finds examples of languages which were described as accentual or non-tonal by earlier scholars which are currently accepted as having tone (e.g., Somali (Hyman 1981) or Jita (Downing 1996)). This means that not all descriptions of accent are reliable. 
To be charitable, it is, in fact, often not straightforward to decide whether a particular pitch system is best described as tonal or accentual. Pitch (especially pitch change) is a principal phonetic correlate of stress, with duration and amplitude or intensity acting as the main secondary cues (Hyman 1977, Odden 1999, and references cited therein). Since raised pitch, especially when it coincides with vowel length, makes a syllable perceptually more prominent, it can often require detailed phonetic and phonological analysis to disentangle whether pitch is playing a more stress-like or a more tone-like role in a particular language. (See Odden 1999 for detailed discussion of this point.) Unfortunately, few phonetic studies of the correlates of stress in African tone languages have been carried out. Most authors reporting on stress do not even make explicit what impressionistic phonetic correlates of stress guide their descriptions. As a result of these problems, it is not uncommon to find conflicting opinions among current scholars about whether perceived prominence in particular languages is best described as stress-accent. Some of these controversies are highlighted in the discussion below.

Another source of controversy arises in languages where the distribution of tone or other features is restricted in such a way as to create prominence asymmetries within morphemes reminiscent of prominence realization in stressaccent systems. What is at issue in such cases is whether accent $/$ metrical structure should be appealed to formally to account for these asymmetries. I review here the principal arguments for accentual structure in conditioning the realization of tone and the distribution of segmental features.

Since the work of McCawley $(1970,1978)$, it has been recognized that some tone systems might better be characterized as pitch-accent systems because tone realization shares properties with stress-accent realization. First, as work like Hayes (1995), Hyman (1977, 1978), Odden (1988, 1999) argue, a typological characteristic of stress is that it is culminative: only one (main) stress may occur within a particular domain and every word must be assigned stress. Similarly, tonal systems are said to be accent-like if they have properties that lead to $\mathrm{H}$ tone culminativity, such as:

- lexical tonal contrasts are defined on morphemes (not moras or syllables), so that at most one $\mathrm{H}$ tone (or tone melody) is found per morpheme;

- $\mathrm{H}$ tone is assigned predictably to every word/lexical morpheme;

- H tones on adjacent syllables or morphemes are eliminated (this is analogous to stress reduction to resolve clash, a metrical process motivated by culminativity).

Secondly, as Hyman (1977) argues, an important function of stress is to demarcate major morpheme edges (stem or word). This explains why main stress in the languages of the world is overwhelmingly located at a word or stem edge: initial, penult or final position. Similarly, tone systems are said to be 
accent-like if $\mathrm{H}$ tones are restricted to occur in these same positions: stem/wordinitial, stem/word/phrase-penult, stem/word/phrase-final (see, e.g., Odden 1988). Finally, tone has been argued to be accent-like if tone and stress interact (van der Hulst \& Smith 1988, Downing 1996). There are two main types of tonestress interaction found in African languages. The position of High tone realization is conditioned by the position of the stressed syllable, or the position of main stress is conditioned by (High) tone.

It should be pointed out that while there is agreement among tone scholars that these tonal properties are analogous to stress-accent, there is widespread disagreement about whether accent or metrical constituency is required as a formal device to distinguish pitch-accent systems from other tone systems. This problem is, in fact, a recurring theme in critical surveys of tone and accent, especially for Bantu languages (see, e.g., Hyman (1989), Downing (1996), Odden $(1988,1995,1999)$ for discussion). To avoid misunderstandings, then, when languages are characterized as having pitch-accent systems in the sections that follow, this means that their tone systems clearly have one or more of the properties described above: culminativity, positional restrictions or tone-stress interactions. These properties are considered accentual for the purposes of this paper, as they lead to tonal prominence asymmetries within morpho-syntactic domains, however they are to be formally analyzed.

Tone is not the only feature with asymmetrical distribution in African languages. In Khoisan languages as well as in a number of West African NigerCongo languages, roots tend to be maximally bimoraic. (Detailed discussion and references are found below.) Although the root contains two consonant positions, in these languages one finds that the full range of consonant contrasts can typically only be found in $\mathrm{C} 1$ position. In $\mathrm{C} 2$ position, contrasts are often reduced drastically, so that only sonorants or some other very restricted subset of consonants can occur. Vowel features show similar asymmetries in some languages, with the full range of contrasts found only in the initial syllable, while contrasts are reduced in the other syllable(s). As Harris (2004) argues particularly forcefully, these asymmetries in the distribution of segmental contrasts within a bimoraic (or bisyllabic) string cannot easily be motivated by appealing to syllable structure. Word-final and prevocalic, non-initial (C2) positions do not form a natural class in terms of syllable structure or features that distinguishes them systematically from $\mathrm{C} 1$. However, if the bimoraic string is a foot, $\mathrm{C} 2$ is in foot-medial position and $\mathrm{C} 1$ is in foot-initial position. In languages that have stress-accent, like English or Danish, there is a strong tendency for full consonantal contrast to be found only in foot-initial position, with contrasts reduced or neutralized in foot-medial position. Likewise, it is common for vocalic contrasts to be realized in the strong syllable of the foot and reduced in the weak syllable (see, e.g., Hayes 1995). Even though African 
languages with contrast distribution asymmetries do not have the usual stressaccent motivating the asymmetries, it is plausible to propose that, universally, these kinds of distributional restrictions are to be accounted for in terms of accent, as they create prominence asymmetries akin to stress accent.

In the remainder of the paper, the accentual systems of African languages are briefly surveyed. The paper is organized by language family: AfroAsiatic, Nilo-Saharan, Khoisan, Malagasy and Niger-Congo. For each family, the emphasis will be not only on examples of stress accent, but also on pitch-accent and accent-like segment distributional asymmetries. It is this diversity of prominence asymmetries that in fact make African languages particularly interesting for research on the typology of accent.

\section{Afro-Asiatic}

The Afro-Asiatic languages are spoken in Northern Africa, in north central Africa as far south as northern Nigeria and in eastern Africa through the Horn. According to Hayward (2000), the modern languages are divided into 5 major branches: Semitic, Berber, Cushitic, Omotic and Chadic. This section will discuss accent patterns in each of these branches in turn.

\subsection{Semitic}

The modern Semitic languages spoken in Africa belong to two major subgroups, Central Semitic (which includes the African dialects of Arabic) and Southern Semitic. Arabic is one of the most widely spoken languages in Africa. It is a major language of Egypt, Libya, Algeria, Tunisia, Morocco and Sudan, and a minority language in Sub-Saharan African countries like Chad and Nigeria. According to the Ethnologue (2000), over 110,000,000 people speak Arabic as a first or second language in these countries. Southern Semitic languages are spoken mainly in Eritrea and Ethiopia. Major languages in this group include Amharic, Gurage, Tigrinya and Tigre.

\subsubsection{African Arabic dialects (Central Semitic)}

In most African Arabic dialects, stress falls on one of the last three syllables in a word, with syllable weight playing an important role in determining which of the last three syllables is stressed (Fischer \& Jastrow 1980; Angoujard 1990; Mitchell 1993: chapter 4). Often the rightmost heavy syllable within this window is stressed, with final syllables only counting as heavy if they are "superheavy": CVVC or CVCC. If there are no heavy syllables, then stress falls on the penult or the antepenult, depending on the other parameters of stress 
assignment in the particular dialect. African Arabic dialects fitting this rightmost, quantity-sensitive pattern include: Tunis Arabic (Angoujard 1990), Egyptian Arabic (Harrell 1957, Hayes 1990, McCarthy 1979; Mitchell 1993), Moroccan Arabic (Kenstowicz \& Kisseberth 1979, citing Harrell 1962; Mitchell 1993), Chadian Arabic (Abu-Absi 1995) and Nigerian Arabic (Owens 1993). Morphological and lexical factors also play a role in conditioning stress in most dialects. For example, the root syllable may be stressed in preference to a nonroot syllable of equal weight; or particular morphemes are always stressed; or some borrowed words keep the stress of the original language. Some of these prosodic and morphological conditions are illustrated in the Egyptian Arabic data below:

(1) Egyptian Arabic stress (Harrell 1957, pp 15-16; Mitchell 1993: 197-198)

(a) Antepenult of 3-syllable word is stressed if all syllables are light búxala 'misers' kátaba 'clerks'

(b) Penult of 3-syllable word is stressed if it is heavy
?axáttu
'I took it (m.)'
maxtába
'library'

(c) Final syllable is stressed if it is super-heavy
fanagíin
'cups'
fihímt
'I/you s.m. understood'

(d) Penult of 3-syllable word is stressed if the initial syllable is a prefixal particle

bi+?álam 'with a pencil'

Even though all the African Arabic dialects share the general parameters of stress assignment outlined above, there is considerable variation in the details of the stress systems among the dialects, as the reader will quickly discover in consulting the works cited.

\subsubsection{Amharic and Tigrinya (Southern Semitic)}

In contrast to Arabic, where word stress-accent is a salient, well-described feature of all dialects, one finds much vaguer descriptions of stress-accent in Southern Semitic languages. For example, in Amharic, a major language of Ethiopia and the most widely spoken Southern Semitic language, stress placement is described in terms of the following tendencies (Leslau 1995; Richter 1987). In general, the penultimate syllable is stressed (arängwáde 'green'). However, in three-syllable words, the first syllable is often stressed rather than the penult if its vowel is more sonorous than the penult vowel (sámuna 'soap'). Vowels preceding geminate consonants are also likely to be stressed (amäs'äggänä 'he thanked'). And stress is also more likely to fall on root vowels than affixal vowels. According to Cowley et al. (1976), certain 
phrasal positions also attract stress, for example, the vowel immediately preceding the copula näw 'he is' is usually stressed (tämarí näw 'he is a student'). These authors all suggest that the main correlates of stress are vowel quality and syllable duration, not pitch and loudness, which might be the reason the position of stress-accent is hard to determine.

Similarly, Bender et al. (1976) state that stress-accent is not particularly salient in Tigrinya, another major Southern Semitic language spoken in Ethiopia and Eritrea. They suggest, however, that stress is typically word-final, and that phrasal stress plays the most important role in determining the rhythm of the sentence.

Recent sketches of individual Southern Semitic languages in Hetzron (1997) confirm that stress in these languages is poorly understood.

\subsection{Berber}

The Berber languages, spoken over a wide area of northern Africa and Saharan Africa, are diverse enough to be broken down into four subfamilies (Hayward 2000). Of these, the languages of Morocco and Algeria appear to be the best described.

Tamazight and Tachelhit (ShilHa) are two major Berber dialects spoken in southern Morocco and Algeria. In both of these dialects, stress is described as falling on the last vowel in the word (Abdel-Massih 1971; Applegate 1958). In Tachelhit, affixes preceding the stem which contain a vowel are also said to be stressed (Applegate 1958). The data in (2) illustrates the final stress pattern of Tamazight:

(2) Tamazight Berber stress (Abdel-Massih 1971, pp. 17-18; capitalized consonants are emphatics)

(a) ndawá

'we cured'

(b) tfafád

(c) dayt:HaDáR

'you (sg) woke up'

'he is present'

\subsection{Cushitic and Omotic}

The Cushitic and Omotic languages are spoken mainly in Ethiopia, Eritrea and Somalia. Major Cushitic languages include Somali, Sidamo, Afar, Oromo, Arbore and Dahalo. Major Omotic languages include Dime and Wolaitta. Omotic was formerly considered a branch of Cushitic, but now is recognized as a distinct subgrouping by most Afroasiatic scholars (Hayward 2000, Amha 1996). Similarities in their accentual systems, however, justify discussing them together. 
Almost all of the Cushitic (and Omotic) languages are tonal, with tone placement conditioned morpho-syntactically (Sasse 1981). Many of these tone systems have the sorts of metrical restrictions on tone realization discussed in Section 1 which have led recent authors to characterize them as pitch-accent systems. For example, tone is subject to culminativity in Somali (Hyman 1981) and Wolaitta (Amha 1996). Only one High tone is allowed per word, and in compounds only the first member retains its High tone. (However, according to Sasse (1981), in some Cushitic languages - see e.g. Iraqw (4), below - not all words must bear High tone, which would be an unusual property in a stress system. And in others, more than one High tone per word can be found.) Also, tone is subject to a positional restriction, occurring generally on the penult or final syllable of the word or stem in languages like Somali, Wolaitta, and Beja (Bedawi) (Hudson1973). (However, it is not phonologically predictable where the High tone will fall, though there are morphologically predictable patterns.) The Wolaitta data in (3) illustrates these points:

(3) Wolaitta pitch-accent (Amha 1996): Only one H per word, on the penult or final of word or stem

$\begin{array}{lll}\text { zaré } & \text { 'lizard' } & \\ \text { záre } & \text { 'relative' } & \text { /zígir + ettá/ } \\ \text { zígir-etta } & \text { 'to gossip' } & \text { /k'aar + ettá/ } \\ \text { k'aar-ettá } & \text { 'to uncover' } & \text { (hayttá 'leaf' + tukké 'coffee') } \\ \text { hayttá } & \text { 'spicy coffee made from coffee } & \\ \text { tukke } & \text { leaves' }\end{array}$

Iraqw, a South Cushitic language spoken in Tanzania, is described as having a very different sort of accent system, with quantity-sensitive stress, as well as tone (Mous 1993). High tones pattern with long vowels in attracting stress. As shown by the data in (4), below, the penult is stressed if it has a long vowel. If the penult has a short vowel and the final syllable has a High tone, then the final syllable is stressed. Otherwise, the first syllable is stressed. (Not all words in this language are assigned High tone.)

(4) Iraqw stress (Mous 1993); accents indicate tone; the stressed vowel is underlined
(a) ba? $\underline{\text { eeso }}$
'bushbucks'
(b) hlooró
'grasshopper'
(c) mugúul
'collarbone'
(d) wawitmo
'king'
(e) bása
'south' 
As we can see from comparing Wolaitta (3) with Iraqw (4), there is considerable variation in the accent systems found in the Cushitic and Omotic languages. One cannot easily generalize about shared parameters of accent assignment or even accent realization in these languages, like we could in discussing Arabic (section 2.1.)

\subsection{Chadic}

There are approximately 140 Chadic languages, spoken mainly in northern Nigeria, Chad, Cameroon, Central African Republic and Niger. Hausa is the most widely spoken, with an estimated 38,000,000 first and second language speakers (Ethnologue 2000). In fact, when second language speakers are included, Hausa ranks as one of the largest African languages excluding Arabic (Hayward 2000).

Chadic languages are all tonal, and it remains controversial whether stress is also a feature of these languages. As Wolff (1993) points out, even though stress has been reported for Hausa, for example, this is likely due to the fact that the correlation between vowel-length and High tone on particular syllables often strikes European ears as stress on that syllable. ${ }^{1}$ (As noted in Section 1, since pitch change and duration are the important phonetic correlates of stress, syllables with these properties are more prominent.) Phonetic work by Dresel (1977) confirms that there is, in fact, no accent independent from High tone in Hausa.

However, Kwami, a Chadic language spoken in Nigeria, is described by Leger (1994) as having stress in words that lack vowel length and High tone. According to Leger, while syllables with a long vowel are always stressed and initial High toned syllables or closed syllables also attract stress (when there is no long vowel), stress is also heard on the final syllable of words lacking High tones or long vowels. These points are illustrated by the data below (accents indicate tones; the stressed syllable is underlined):

(5) Kwami stress (Leger 1994, pp 91-92)

háakù 'yawn (noun)'

gàrìngáalè 'bicycle, wheel'

kábá 'inside'

kòmkáy 'pluck'

kùrè 'fence'

1 Thanks to Paul Newman (p.c.) for bringing this to my attention. It is telling that Newman's (2000) truly encyclopedic grammar of Hausa contains no discussion of stress, although the phonology, tone and intonation of Hausa receive detailed coverage. 
Clearly more phonetic studies of the correlates of stress in Chadic languages are necessary to disentangle this controversy.

\section{$3 \quad$ Nilo-Saharan Languages}

Nilo-Saharan remains the most diverse and controversial of the four African language families (see Bender 2000 for an up to date discussion). It contains a dozen sub-families whose speakers are scattered across the northern Democratic Republic of the Congo (DRC), southern Sudan, Uganda and Kenya.

Many of the languages have not been described in detail, making it difficult to ascertain what role, if any, stress-accent plays in this language family. Most of those which have been described are said to have tone systems, with no mention of stress. However, Dholuo (E. Nilotic) is described by Tucker (1993) as having stress as well as tone. Stress is assigned to the stem-initial vowel. (That is, stress placement is determined by morphological, not phonological, position.) When a word is in phrase-final position, the stressed vowel is noticeably lengthened, at least in some dialects. (Tucker unfortunately does not describe other correlates of stress, though his discussion implies length is not the only one.) Since stress is morphologically determined, words of identical lengths but different morphological structures will be stressed on different syllables, as shown in (6a). And adding suffixes does not change the position of stress away from the stem vowel, as shown in (6b).

(6) Dholuo stress (Tucker 1993, p 18); stressed vowels are underlined; accents indicate high tone
(a)
rathî
'cobra' vs
rawo
'hippo'
(b) ra+hí +nì
'this cobra' vs.
rawo+ni
'this hippo'

Similarly Lango (W. Nilotic), is described by Noonan (1992) as having stress as well as contrastive tone. As in Dholuo, stress (realized as increased amplitude and length) is assigned to the root-initial vowel, as shown in (7a). (Only borrowed words have stress on other root syllables.) And in compounds, the rightmost word of the compound receives primary stress, as shown in (7b).

(7) Lango stress (Noonan 1992, pp 42-43); stressed vowels are underlined; accents indicate high tone
(a) àtbòlò
'plaintain'
vs. mà̀kâc
'scissors'
(b) píg átbólò
'plaintain juice' 
Dinka and Shilluk, two other Western Nilotic languages, are described by Gilley (2003) as also having contrastive tone and grammatical (morphologically- or syntactically-conditioned) stress. Surprisingly, even though vowel length is contrastive in these two languages, stressed vowels are said by Gilley (2003) to be shorter than unstressed vowels (recall from section 1 that lengthening is the usual correlate of stress) but have greater intensity than unstressed vowels.

While these Nilotic languages have morphemic stress, some Nilo-Saharan languages apparently have positional stress. For example, both Hyman (1977) and Ruhlen $(1975,1976)$ list Mangbetu (Central Sudanic) as having dominant penultimate stress (as well as tone). Finally, Nicolaï \& Zima (1997) and Heath (1999) note that the Western dialects of Songhay have a stress-accent system, rather than the tonal one found in Proto-Songhay and the other modern Songhay dialects. Unfortunately, no description of the stress system is provided in these works.

\section{$4 \quad$ Khoisan languages ${ }^{2}$}

The Khoisan languages represent the smallest of the four large African language groups. According to Güldemann \& Vossen (2000), it is estimated that there might have been as many as 100 Khoisan languages in the past, spoken over much of Southern Africa. Today, barely 30 Khoisan languages survive, with the largest communities concentrated in Namibia and Botswana. Very few of these languages have been described in any detail, and it seems likely that many of the remaining Khoisan languages will become extinct before they can be carefully documented.

All the Khoisan languages are described as having tone, and I could find no discussion of stress in the existing Khoisan literature. However, recent work points to other evidence for the importance of foot structure in particular Khoisan languages. One sort of evidence comes from the skewed distribution of consonants in initial vs. medial and final position within stems (which are minimally bimoraic). Traill (1985) reports that most of the 116 contrastive consonants of !Xóõ are only found morpheme-initially. Morpheme-medially (intervocalically), only 6 consonants occur, all arguably sonorants. Morphemefinally, only 3 consonants, all nasals, occur. As noted in Section 1, intervocalic and final consonant-position do not form a syllabic natural class. Instead, the restrictions found on consonants in these positions are best explained by proposing they are foot-bound. Foot-initial position licenses all consonants; non-

2 Thanks to Amanda Miller-Ockhuizen for helpful discussion of the points raised in this section. See Güldemann \& Vossen (2000) for an up to date overview of the sociolinguistic status, classification and grammatical structure of Khoisan. 
initial positions license only sonorants. Miller-Ockhuizen (2001b) shows that a similar asymmetry in consonant distribution is also found in Ju|'hoansi, and that marked vocalic phonation is only found in foot (or root) initial syllables.

Another piece of evidence for foot structure comes from minimality requirements on roots. In both !Xóõ (Traill 1985) and Ju|'hoansi (MillerOckhuizen 2001a, b) roots are minimally bimoraic. As Miller-Ockhuizen (2001a, b) shows, roots described as CV by other authors actually contain significantly lengthened vowels, so that they are similar in overall duration to $\mathrm{CVCV}$ roots. This requirement is best explained if roots must minimally contain a single bimoraic foot. Finally, in both !Xóõ (Traill 1985) and Ju|'hoansi (Miller-Ockhuizen 2001a, b), the possible tone patterns for roots are very limited. Traill (1985) argues these can best be explained if the entire root morpheme (or root foot), not each mora of the root, is associated with a root tone melody. As noted in Section 1, above, it is considered diagnostic of pitchaccent languages for tone melodies to take a morpheme as their domain rather than the syllable. (However, see Miller-Ockhuizen (1998) and Haacke (1999) for alternative analyses of these restricted tonal patterns.)

Traill (1985) argues that adaptations of borrowings into !Xóõ provide evidence that the consonant distribution and minimality requirements on stems (roots) are not static lexical generalizations but rather productive processes. For example, Afrikaans lorrie 'lorry' and koppie 'cup' both have short initial vowels in the original language, but lorrie is borrowed as nòli (with a short vowel) while koppie is borrowed as kóopì (with a long vowel). The explanation for this is that lorrie has a medial sonorant, so fits the consonant distribution restrictions on root-second consonants. However, koppie has a medial stop, so the initial vowel is lengthened to make the initial syllable a possible bimoraic root. The second syllable can now be interpreted as a suffix licensing a morpheme-initial obstruent.

The restrictions on the distribution of consonants and marked vocalic phonation suggest that it is the morpheme-initial (or foot-initial) syllable that counts as strongest in Khoisan languages. However, there are also restrictions on the distribution of vocalic features that point to the second syllable as stronger, at least in Ju|'hoansi. In this language, some reduced vowels only occur in the first syllable of bisyllabic roots, never in the second syllable (Miller-Ockhuizen, p.c.; see, too, Miller-Ockhuizen (1999) for a more detailed discussion of vowel distribution restrictions). Obviously, more work needs to be done on the phonology of these languages to reach a better understanding of how these conflicting foot-bound prominence asymmetries could be resolved. 


\section{$5 \quad$ Malagasy}

Malagasy, spoken on the island of Madagascar, is the westernmost Austronesian language and the only Austronesian language spoken in Africa. According to Beaujard (1998) and Keenan \& Polinsky (1998), main stress in Malagasy is always assigned to one of the last three syllables of a word. Main stress generally falls on the penult, as shown in (8a). However, lexical and morphological factors interfere with this basic stress pattern. Words ending in $-t r a,-k a,-n a$, and $-n a$ generally receive main stress on the antepenult. The minimal contrast between $(8 a)$ and $(8 b)$ shows that the antepenult stress pattern is lexically conditioned. The final syllable can also be stressed in certain lexical and morphological contexts. As shown in (8c), some roots ending in /e/ are stressed on the final syllable. Morphologically-conditioned final stress is illustrated by the contrast in (8d). In words of four or more syllables, secondary stress is assigned to every second syllable preceding the syllable with main stress, as shown in (8e):

(8) Malagasy stress patterns (Beaujard 1998: 23; Keenan \& Polinsky 1998: 570); vowels with main stress are underlined

\begin{tabular}{|c|c|c|c|}
\hline (a) & Regular penult stress: & tanana & 'village' \\
\hline (b) & Antepenult stress: & tănana & 'hand' \\
\hline (c) & Final stress 1: & ome & 'act of giving' \\
\hline (d) & Final stress 2: & milazza & 'say, active' \\
\hline & vs. & milaza & 'say, passive' \\
\hline e) & Secondary stress: & $\begin{array}{l}\text { sòmaritaka } \\
\text { pàtaloha }\end{array}$ & $\begin{array}{l}\text { 'preoccupied' } \\
\text { 'pants' (<French 'pantalon') }\end{array}$ \\
\hline
\end{tabular}

\section{$6 \quad$ Niger-Congo ${ }^{3}$}

The Niger-Congo language family is the largest in Africa - in fact, one of the largest in the world - containing 1436 languages grouped into some 20 subfamilies spoken by $360+$ million speakers distributed over most of subSaharan Africa (Williamson \& Blench 2000). ${ }^{4}$ The languages in this family are overwhelmingly tonal. Only the North Atlantic subfamily is generally non-tonal

3 The information about the distribution of the subfamilies and languages discussed in this section comes from Williamson \& Blench (2000) and the Ethnologue (2000).

4 See, too articles in Bendor-Samuel (1989) for a detailed, current discussion of the classification and important grammatical features of the Niger-Congo languages. 
(though individual languages in other subfamilies have been described as lacking tone). Several of the tone languages are described as also having stressaccent. In others, we find evidence for pitch-accent, as tone placement is subject to the metrical conditions, like culminativity and attraction to word-peripheral position, discussed in Section 1. And several show accent-like asymmetries in consonant distribution.

Since this is a large, diverse language family with many subfamilies, this section is organized by subfamily, beginning with Atlantic. Next, other West African subfamilies are discussed. (If a subfamily is not discussed, that is because no discussion of stress or other evidence for accent in languages of that subfamily was found.) Bantu languages are discussed last. Since this is the largest subfamily and the accentual properties of Bantu languages have been extensively studied, this lengthy subsection is further broken down by topic: stress-accent, accent-like distribution asymmetries and pitch-accent.

\subsection{Atlantic}

The Atlantic languages are spoken mainly along the North Atlantic coast of Africa, from the mouth of the Senegal River (and along the river to the interior) south to Liberia. Major languages in this group include Fufulde, Wolof, the Diola group and Serer.

Within the Atlantic subfamily, only most North Atlantic languages are non-tonal. One finds a surprising range of stress systems within the North Atlantic group. Sapir (1965) shows that Diola-Fogny, spoken in Gambia and Senegal, has morphologically-determined stress. The first syllable of a bound root receives primary stress. Some final clitics, like possessives, the definite article and the third person object particle, also receive primary stress, even when this leads to adjacent primary stresses. These points are illustrated below:

(9) Diola-Fogny stress (Sapir 1965, p. 9); '[' marks the edge of a bound root; stressed vowels are underlined

(a) $\varepsilon$-[ja-men

'goat'

(b) $\varepsilon$-[ja-men-ney

'the goat'

(c) $\varepsilon$-[ja-men-nom

'my goat'

(d) pa-ni-[ka-ț

'I will leave him'

(e) ni-te-[tek

'I hit'

(f) ni-[ka-no

'I dress myself'

(g) ni-[ka-no

'I dress him'

However, in other North Atlantic languages, phonological factors determine stress placement. In Senegalese Wolof, for example, stress is assigned to the 
initial syllable of the word (Ka 1988). Non-initial heavy syllables (CVV) are assigned secondary stress (except a heavy syllable adjacent to an initial syllable receives main stress). In the Pulaar variety of Fufulde, the heaviest syllable in the word $(\mathrm{CVVC}>\mathrm{CVV}>\mathrm{CVC}>\mathrm{CV})$ is assigned main stress (except the final syllable is never stressed). If the heaviest syllables are of equal weight (Niang 1997), the leftmost receives main stress and the other(s) secondary stress. ${ }^{5}$ These points are illustrated in (10), below:

(10) Wolof stress patterns (Ka 1988)
wonewu
doxantuji
teraanga
jụmtukaay

(b) Pulaar stress patterns (Niang 1997)

$\begin{array}{ll}\text { aduna } & \text { 'world' } \\ \text { asamaan } & \text { 'sky' } \\ \text { dadorde } & \text { 'waist' } \\ \text { tallorde } & \text { 'place for rolling' } \\ \text { halkaade } & \text { 'to perish' } \\ \text { haalpulaar?en } & \text { 'speakers of Pulaar' }\end{array}$

In Noon (Cangin), spoken in Senegal, the penult is regularly assigned stress, except in three syllable words where stress instead is on the initial syllable (Soukka 2000) ${ }^{6}$. Neither syllable weight nor morphological boundaries play a major role in stress assignment. Interestingly, Noon also has high pitch assigned to the penult of every word. As shown in (11), pitch and stress generally coincide. However, in three-syllable words, high pitch is assigned to the penult while stress is on the initial syllable, showing that pitch and stress are independent in this language.

5 See Anyanwu (2002) for discussion of the phonetic correlates of stress in the Fuuta Jaloo variety of Pular, spoken in Guinea.

6 As Hyman (1977) notes, it is cross-linguistically common for languages with regular penult stress to assign stress to the initial syllable of three-syllable words or stems. (Additional examples of this pattern in African languages are illustrated in (12) and (16), below.) Hyman (1977) proposes that a plausible functional explanation for this alternation is that the most important phonetic cue to stress is a pitch fall over either the first two or the last two syllables of the word. When the two edges are in conflict, as when penult stress is assigned to a three-syllable word, stress tends to shift to the initial syllable. It is, however, problematic for this general explanation that High tone remains on the penult in three syllable words in Noon, even when stress is on the initial syllable. It would be interesting to know what phonetic cues there are to stress on the initial syllable. 
(11) Noon pitch and stress (Soukka 2000; p. 42); stressed vowel is underlined; accent indicates High tone

kédik

'tree'

lëgísoh

'disentangle, explain'

këwdí:ri:

'the pot'

hotubitéli:

'the eucalyptus'

The question that arises is how, within the same subfamily, one could find languages with main stress at the opposite edges of a word: root-initial in DiolaFogny vs. penult in Noon. As Hyman (1977) shows, this range of stress patterns is actually not unusual in families that include languages with quantity sensitive stress assignment. For example, Proto-Altaic is reconstructed with initial stress, but Turkish has regular final stress while in Khalka Mongolian stress placement is quantity sensitive. Hyman (1977) suggests the following plausible diachronic scenario relating these diverse systems. In the Proto-language, stress would be assigned to one edge of a morpheme. Since duration is a phonetic cue for stress, it is a natural change for stress to be attracted away from a morpheme edge towards a long syllable. If this quantity-sensitivity condition is lost in a subsequent change, then stress would again be assigned to a word or morpheme edge. At this stage of historical development, it would be equally natural for stress to be assigned either to the same edge as in the Proto-language or to the opposite edge.

\subsection{Adamawa-Ubangi}

The Adamawa-Ubangi languages are spoken in north-central Africa from northwest Nigeria as far as the DRC and Sudan. The Ubangi language Zande, spoken in the DRC and Sudan, has been described by Tucker (1959) as having stress, as well as tone. As shown in (12), stress ('accent d'intensité') falls on the first syllable of two and three syllable words (prefixes are ignored) and the penult of longer words. (Notice, this is the same pattern found in Noon, as shown in (11), above.) The first syllable of each half of a compound is also stressed.

(12) Zande stress patterns (Tucker 1959, p. 48); stressed vowel is underlined; accents indicate tone

ngìrìmò

a- ngì̀ìmò

fùfùr’äfù

kpòto-ngbâa

runngudi-rúngúdí 'flood'

'floods'

'butterfly'

'rabbit (skin-mouth)'

'red-hot' 
Tone and stress are apparently independent. However, the correlates of stress are said to be vowel lengthening, more energy and a raise in pitch. As Tucker (1959) notes, the interaction between stress and pitch makes the Zande tone system difficult to establish.

\subsection{Kru}

Kru languages are spoken throughout Liberia and in adjacent areas in the Ivory Coast. According to Marchese (1989), Kru languages are tonal. Stress is reported for one language in this group, Grebo. It is controversial whether Grebo actually has stress, however. According to Innes (1966), stress and tone are independent in Grebo, with some words distinguished only by stress (the stressed vowel is underlined): eg., sono (21 tone pattern) 'sting (noun)' vs. sono (21 tone pattern) 'smell (noun)'. Newman (1986) reports, though, that he was unable to identify or confirm the stress patterns described by Innes. Indeed, Innes gives no clear description of the correlates of stress and suggests that contrastive stress can be neutralized in certain emphatic pronunciation styles. More work is certainly needed to resolve this controversy.

\subsection{Mande}

Mande languages are spoken widely over the western half of West Africa, with major communities found from Senegal to the Ivory Coast, along the coast, and towards the interior as far as Mali and Burkina Faso. Manding is the major language in this subfamily.

According to Dwyer (1989), Mande languages are tonal. Stress-accent has also been described for some languages in this group, like Kpelle, a Northwest Mande language. According to Welmers (1973), in Kpelle words with a High tone on the initial syllable or words that are Low-toned throughout, stress is assigned to the initial syllable. Words with non-initial High tones, e.g., with Mid-High-Low tone pattern, have stress assigned to the High-toned syllable. Words with a Mid tone throughout have no syllable appreciably more prominent. If High tones can be considered the equivalent of heavy syllables, this stress pattern is, then, analogous to the quantity-sensitive, leftmost stress pattern of Pulaar (10b), discussed above. What makes this an unusual stress system is that it lacks culminativity, since Mid-toned words are not stressed.

The phonotactics of some West Mande languages also display accent-like properties. According to Vydrine (to appear), most roots are maximally bisyllabic, and the distribution of segments is not symmetrical in bisyllabic words. In $\mathrm{C} 2$ position some phonological contrasts are neutralized or reduced, and Vydrine notes a tendency for $\mathrm{C} 2$ consonants to be lenited or deleted within 
the West Mande languages. In $\mathrm{C} 1$ position a much fuller range of consonant contrasts is realized. Vowel contrasts are also often reduced in the second syllable: long vowels (in the languages where they exist) cannot occur wordfinally in many of these languages. Finally, the tone system of many West Mande languages shows culminativity in the sense that the morpheme, not the syllable, is the domain of tone contrast. ${ }^{7}$ As argued in Section 1, these asymmetries in the distribution of consonants, vowel length and tonal contrasts are plausibly considered accentual phenomena since they increase the prominence of some syllables at the expense of others in the word.

\subsection{Gur}

The Gur languages are spoken in a belt from Mali through Burkina Faso to northern Togo and Benin. Mò:ré, with 1,700,000 speakers, is the major language in this subfamily.

Gur languages are tonal, and it is apparently controversial whether or not stress-accent is a feature of these languages. Naden (1989) suggests that what gives the impression of syllable prominence in Gur languages is a combination of High tone, intonation peak and vowel length. (See the discussion in Section 1, above.) However, Olawsky (1999) describes Dagbani as having regular stress on the penult independent of tone or vowel length. And Koromfe (Rennison 1997), Supyire (Carlson 1994) and Mò:ré (Cann 1976) have all been described as having stress on the word-initial or root-initial syllable. As Cann shows, in Mò:ré stress is independent of tone: sídá 'spouse' vs sìbrì 'fruit of the Lannea oleosa'. Note that the initial syllable of both words is stressed, even though one has a High tone and the other a Low tone.

\subsection{Delta-Cross}

As the name implies, the Delta-Cross languages are spoken in the Cross River area of southeastern Nigeria. These languages are all tonal with no reported stress-accent. However, Faraclas (1989) notes that several languages in this group have asymmetrical distributions of segmental contrasts within an initial bisyllabic or bimoraic string. As argued in Section 1, these asymmetries are best

7 Leben (2002) argues that a bisyllabic constituent, the tonal foot, is the domain for tone association in the Mande language, Bambara. As both syllables within the foot can bear High tone, we do not necessarily find the sort of tonal prominence asymmetry which is considered diagnostic of accent in this paper. The interested reader can consult Leben (2002) for arguments that the tonal foot provides non-accentual evidence for the interaction of metrical constituency and tone. 
explained by appealing to foot structure, as they result in accent-like prominence asymmetries.

For example, in Gokana (Hyman 1990), inflected stems can have up to two consonants. The stem-initial $(\mathrm{C} 1)$ consonant can be any one of the 15+ contrastive consonants of the language. However, only three of these consonants can occur in C2 position. As Hyman (1990) shows, this restriction on C2 holds whether it is in onset or coda position, so that it is not determined by syllable structure. A better explanation of the asymmetry is to propose that full consonant contrasts can only be realized in foot initial position. In foot medial position, contrasts are drastically reduced.

Similar distributional asymmetries between $\mathrm{C} 1$ and $\mathrm{C} 2$ are found in Efik (Hyman 1990, citing Cook 1985). Other evidence for the importance of the bimoraic foot in Efik comes from an alternation found in the negative suffix. As Hyman (1990) shows, the negative suffix is realized as [-ké] after a CVC or a

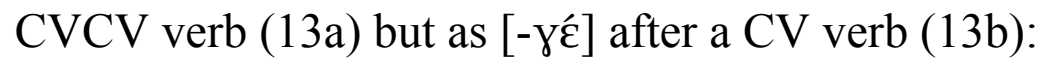

(13) Efik alternations in the negative suffix (Hyman 1990; figs. (32), (33))

(a) After CVC and CVCV verbs m-bòm-ké

'I am not breaking'

ý-wàt-ké

ń-dòri-ké

ń-sàyá-ké

'I am not paddling'

'I am not putting on top (of)'

'I am not walking'

(b) After CV verbs ${ }^{8}$

$$
\begin{aligned}
& \text { n- } \\
& \text { ń-sर́- }-\gamma \tilde{\varepsilon} \\
& \text { ḿ-bذ̀-yó } \\
& \text { ý-kà-yá }
\end{aligned}
$$

'I am not coming',
'I am not looking at'
'I am not receiving'
'I am not going'

The context for the alternation is best captured by proposing that $[\mathrm{k}]$ occurs in foot-initial position (CVC and CVCV verbs form a bimoraic foot on their own and the negative suffix begins a new foot), while gamma occurs in foot-medial position. (Gamma is one of the three consonants which can occur in $\mathrm{C} 2-$ foot medial - position in Efik.)

As Akinlabi \& Urua (2002), Harris (2004) and Urua (1999) show, Ibibio phonology also provides several motivations for foot structure. Distributional asymmetries between $\mathrm{C} 1$ and $\mathrm{C} 2$ are found, similar to those described for Efik and Gokana. There are also contrast asymmetries between V1 and V2, confirming the initial $\mathrm{CV}$ as the strong position within the bisyllabic foot. As in

8 Notice that the vowel of the negative suffix also harmonizes with the root vowel when it is within the same foot as the root vowel. 
Efik, various allomorphic processes take as their conditioning context the segment's position within the foot. Finally, the foot defines a prosodic template for some verb paradigms. For example, Akinlabi \& Urua (2002), Harris (2004) and Urua (1999) show that the vowel of CV roots is lengthened and that of CVVC roots is shortened when certain consonant-initial suffixes are added:

(14) Ibibio root vowel length alternations before the negative/reversive suffix CVVC roots

\begin{tabular}{|c|c|c|c|}
\hline $\begin{array}{l}\text { fî̀p } \\
\text { kóoy } \\
\text { wúúk }\end{array}$ & $\begin{array}{l}\text { 'suck' } \\
\text { 'hang on hook' } \\
\text { 'drive in' }\end{array}$ & $\begin{array}{l}\text { fìp-pé } \\
\text { kôj-yj́ } \\
\text { wák-kó }\end{array}$ & $\begin{array}{l}\text { 'remove sucked objec } \\
\text { 'remove from hook' } \\
\text { 'remove an object dri }\end{array}$ \\
\hline \multicolumn{4}{|c|}{ CV roots } \\
\hline kă & 'go' & ń-kàà-yá & 'I am not going' \\
\hline sé & 'look' & ń-séé-yé & 'I am not looking' \\
\hline dî & 'come' & 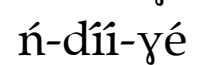 & 'I am not coming', \\
\hline
\end{tabular}

They argue these vowel length alternations are best explained by proposing the output of the root+suffix combination must be parsed as a heavy-light trochee.

Accent-like distribution asymmetries like those found in Delta Cross seem to be fairly widespread in West African Niger-Congo languages. Elsewhere, they have been reported for Ijoid (Williamson 1978), Kainji and Platoid (Gerhardt 1989) and Adamawa (Boyd 1989) languages. (Sections 4, 6.4, and 6.7.2. in this paper discuss similar asymmetries for Khoisan, Mande and Bantu languages, respectively.)

\subsection{Bantu}

The Bantu languages represent the largest group within Niger-Congo, comprising 500+ languages, spread over most of Africa south of a line extending from southern Cameroon in the west to southern Somalia in the east. While most Bantu languages have been described as tonal (and Proto-Bantu is reconstructed as having two tones), almost all are also described as having accentual properties. Many of the languages have stress-accent independent from tone, while a few have lost tone to retain only stress. Further, many Bantu tone systems have been described as having pitch accent features. And several languages show evidence of accent-like distribution asymmetries. This section surveys the role of accent in Bantu, beginning with the relatively uncontroversial stress patterns and segment distribution asymmetries and ending with a discussion of the more controversial role of accent in defining properties of Bantu tone systems. 


\subsubsection{Stress-accent in Bantu languages}

Stress-accent is widely reported for languages from all over the Bantu-speaking area. Some of the earliest work on Bantu prosody, like Werner (1919), observes that the penult syllable is the most likely to be stressed. The table below, which lists a geographically diverse set of Bantu languages, shows that this is indeed the overwhelmingly most common pattern:

(15) Summary table of stress-accent in Bantu languages

\begin{tabular}{|c|c|c|c|}
\hline Language & $\underline{\text { Stress position }}$ & Tone? & $\underline{\text { Source }}$ \\
\hline Bondei & penult & yes & Philippson 1998 \\
\hline Chichewa & penult & yes & Odden 1999 \\
\hline Chimwi:ni & penult & no & $\begin{array}{l}\text { Kisseberth \& Abasheikh } \\
\text { 1974; Kisseberth } 2000\end{array}$ \\
\hline Chizigula & penult & yes & Philippson 1998 \\
\hline Digo & penult & yes & Philippson 1998 \\
\hline Giryama & penult & yes & Cassimjee \& Kisseberth 2000 \\
\hline Kinande & penult & yes & $\begin{array}{l}\text { Mutaka 1994; } \\
\text { Mutaka \& Hyman } 1990\end{array}$ \\
\hline Kirufiji & penult & yes & Odden 1999 \\
\hline Kishambaa & penult & yes & Odden 1999; Philippson 1998 \\
\hline Kituba (Kongo véhiculaire) & penult & no & Odden 1999 \\
\hline Lingala, eastern dialects & penult & yes & Guthrie \& Carrington 1988 \\
\hline Lingala, western dialects & stem-initial & yes & Guthrie \& Carrington 1988 \\
\hline Luvale & $\begin{array}{c}\text { penult (and verb } \\
\text { stem initial) }\end{array}$ & yes & Horton 1949 \\
\hline Makonde & penult & yes & Odden 1999, Liphola 2001 \\
\hline Namwanga & penult & yes & Bickmore 2001 \\
\hline $\begin{array}{l}\text { Nguni (Zulu, Xhosa, Swati, } \\
\text { Ndebele) }\end{array}$ & penult & yes & Doke 1954 \\
\hline Nyakyusa & penult & no & Felberg 1996 \\
\hline Nyooro-Tooro & penult & no & Taylor 1985 \\
\hline Pogolo & penult & no & Odden 1999 \\
\hline Runyankore, Low & penult & no & Johnson 1976 \\
\hline Shona & penult & yes & Doke 1954 \\
\hline Sotho-Tswana & penult & yes & Doke 1954 \\
\hline Swahili & penult & no & Ashton 1969 \\
\hline Taita & penult & yes & Odden 1999 \\
\hline Tsonga & penult & yes & Doke 1954 \\
\hline Tumbuka & penult & no & Odden 1999 \\
\hline Venda & penult & yes & Doke 1954 \\
\hline
\end{tabular}


The other common position for stress is stem-initial, as reported for western dialects of Lingala by Guthrie \& Carrington (1988). As shown in the contrasting pair below, the penult bears main stress in the east, while the first syllable of the stem is stressed in the Lower Congo River area. When the stem contains more than three syllables, the penult is also stressed in the Western area: ${ }^{9}$

(16) Lingala stress (Guthrie \& Carrington 1988); '[' marks stem edge; stressed syllable is underlined

(a) stress on penult in the East: to-ko-[kanisa

'we shall think'

(b) stress on stem-initial in West to-ko-[kanisa

'we shall think'

(c) stress also on penult in West

ba-ko-[palanganissa

'they will scatter' for longer stems

The most commonly reported phonetic correlate of penult stress, for both the tonal and non-tonal languages listed above, is vowel lengthening, with sources often noting that lengthening is most noticeable when words are in phrase-final position. ${ }^{10}$ However, Chimwi:ni presents an interesting exception to the generalization that stress and positionally restricted vowel length tend to coincide. ${ }^{11}$ As Kisseberth \& Abasheikh (1974) and Kisseberth (2000) show, the surface distribution of long vowels in Chimwi:ni is restricted: they can only occur in the penultimate or antepenultimate syllable of a phrase. Since these positions are familiar from languages like Latin as typical ones for the realization of stress, one might propose that length correlates with stress-accent (Selkirk 1986). However, Kisseberth \& Abasheikh (1974) and Kisseberth (2000) make clear that the vowel length distribution pattern does not correlate with accent. Accent is realized as a higher pitch, assigned in the default case to the penult syllable of a phrase, or to the final syllable in some grammatical constructions, never to the antepenult. As intonational pitch is aligned with these accents, not with syllables containing long vowels, accent is arguably the more

9 As Rob Goedemans (p.c.) points out, Western Lingala (16b, c) very plausibly illustrates yet another example of the pattern found in Noon (11) and Zande (12), where regular stress assignment to the penult in words/stems of more than three syllables alternates with stress assignment to the initial syllable in shorter words/stems.

Liphola (2001) shows that unstressed mid vowels preceding the lengthened penult reduce to [a] in his dialect of Makonde. That is, reduction in contrasts in unstressed position enhances the prominence of stressed vowels. It is an interesting research question whether similar stress-conditioned vowel reduction is found in other Bantu languages.

11 Chimwi:ni is a non-tonal dialect of Swahili spoken on the coast of southern Somalia. As Abasheikh \& Kisseberth (1974) and Kisseberth (2000) show, Chimwi:ni has an underlying vowel length contrast as well as several contexts where only long vowels predictably occur. 
stress-like form of positional prominence in this language. The data below provide examples of the mismatch between positionally restricted vowel length realization and positional accent in Chimwi:ni:

(17) Chimwi:ni (Kisseberth 2000); accents indicate stress accent, colons indicate vowel length

(a) ku-lokóta

(b) x-furahikíla

'to pick up'

(c) ku-da:rána

'to be pleased for'

(d) $x$-sa:fíra 'to touch one another'

(e) fí:le 'to travel'

\section{n-dála}

's/he died'; file: n-dála 'hunger'

(f) m-zé:le 'old man'; úje 'that'

's/he died of hunger'

'that old man'

\subsubsection{Accent-like segment distribution asymmetries in Bantu languages}

In most Bantu languages there is a marked asymmetry between the segmental contrasts found in the first syllable of the stem compared with subsequent stem syllables. As Bennett (1978; cited in Hyman 1989) shows, the full Proto-Bantu seven-vowel contrast is only realized in the stem-initial syllable. Elsewhere, a reduced number of contrasts is found. Similarly, only the stem-initial vowel contrasts systematically for tone. Noun prefixes and verb derivational suffixes do not contrast for tone. Vowel length contrasts are also mainly confined to the stem-initial syllable. Bennett (1978) argues that these asymmetries can all be best accounted for if the stem-initial syllable is accented. As argued in Section 1 (and subsequent sections), we expect, cross-linguistically, a fuller distribution of features under accent and reduced contrasts in unaccented syllables. It is, in fact, a traditional claim about Bantu languages (see e.g. Werner 1919) that the steminitial syllable bears what she calls "etymological stress." (As we saw in the previous section, in Western Lingala the stem initial syllable receives stressaccent, and in the next section we shall see that it also is accented for tone realization in some Bantu languages.) It is not clear in much of the traditional literature what is meant by stress, but certainly the tone and vowel quality asymmetries make the stem-initial syllable more perceptually prominent.

Other evidence for accentual prominence of the stem-initial syllable comes from some NW Bantu languages where we find the same sorts of consonant distribution asymmetries familiar from Khoisan and other West African Niger-Congo languages. For example, Hyman (1990, 2000) shows that in Basaa, roots have the shape $\mathrm{C} 1 \mathrm{~V}(\mathrm{C} 2)$, and stems are maximally three 
syllables. All 22 consonants of the language contrast in $\mathrm{C} 1$ position. In $\mathrm{C} 2$ position, only 12 consonants can occur, and even fewer are possible in C3. Particularly striking evidence that these restrictions are accent based, not syllable based, comes from restrictions on voicing contrasts in obstruent stops. As Hyman (1990, 2000) shows, C1 is voiceless while C2 is voiced (and continuant between vowels) whether $\mathrm{C} 2$ is in the onset or coda:

(18) Basaa voicing complementarity (Hyman 1990, pp 184-185)

(a) $\mathrm{P}, \mathrm{T}, \mathrm{K}$ in $\mathrm{C} 1$ position are voiceless ([lì-] is a noun class prefix preceding the root)

$\begin{array}{llll}\text { póś } & \text { 'to borrow' } & \text { lì-pàn } & \text { 'forest' } \\ \text { táy } & \text { 'to deny' } & \text { lì-tàm } & \text { 'fruit' } \\ \text { kém } & \text { 'to groan' } & \text { lì-kùy } & \text { 'owl' }\end{array}$

(b) $\mathrm{P}, \mathrm{T}, \mathrm{K}$ in $\mathrm{C} 2$ position are voiced (three dots indicate phrase-medial form)

(bi) Onset

hí -îl

kér-êl

bú y-ûl 'to breathe for/at'

'to pick for/at'

'to break for/at' (bii) Coda

héb...

kéd...

bóg... 'to breathe'

'to pick fruit'

'to break'

Similar restrictions are found in other NW Bantu languages like Kukuya (Teke) and Tiene. According to Hyman (1989), stems in Kukuya are maximally three syllables. The first stem consonant can be any of the $30+$ contrastive consonants of the language, while only six consonants are found in $\mathrm{C} 2$ and $\mathrm{C} 3$ position. Likewise, in Tiene (Hyman \& Inkelas 1997), stems are maximally three syllables. As in Basaa and Kukuya, all consonantal contrasts are found in C1 position. Hyman \& Inkelas do not discuss restrictions on $\mathrm{C} 2$ in bisyllabic stems. However, they show that in trisyllabic stems C2 and C3 must agree in nasality, and $\mathrm{C} 2$ must be coronal while $\mathrm{C} 3$ must be non-coronal. These asymmetries in consonant distribution fall out if the stem-initial syllable is accented, and if, cross-linguistically, lack of accent is the best explanation for reductions in contrast.

\subsubsection{Pitch-accent features of Bantu tone systems}

That tone realization in Bantu languages, especially in verbs, has accentual properties has been recognized since McCawley (1970). As this work emphasizes, what makes it difficult to characterize Bantu tone systems as accentual is that many languages with distinctive accentual properties also have many properties characteristic of more 'tonal' systems. As a result, much theoretical work on Bantu tone has focussed on how the interaction between the 
accentual and tonal properties should best be formalized, and even whether the distinction should be formalized. (See Downing (1996), Hyman (1989) and Odden $(1988,1995,1999)$ for critical surveys of accent in Bantu. And see Cassimjee \& Kisseberth (1998) for a current prosodic approach to Bantu tone. ${ }^{12}$ ) This section naturally focuses on the accentual properties of Bantu tone systems, and ignores the more tonal properties. Because Bantu accent is such a theoretically controversial topic, two caveats are in order. First, it should be made clear that pitch-accent is used here to refer to particular stress-like properties of tone realization discussed in Section 1 - culminativity, positional restrictions and tone-(stress) accent interactions - and not to any particular formal theory of accent. The interested reader should also consult the works cited to gain an appreciation of how the more tonal properties of the system interact with the pitch-accent properties highlighted here. ${ }^{13}$

\subsubsection{Culminativity effects}

As noted in Section 1, a distinctive characteristic of stress-accent is that it is culminative. In many Bantu languages, we find culminativity restrictions on High tones within stems or words that make these tone systems resemble pitchaccent systems. First of all, just as in stress systems only one (main) stress is found per word or stem, in many Bantu languages only one High tone is found per word or stem. As noted in the preceding section (see, too, Kisseberth \& Odden 2003), only the stem-initial syllable of verbs contrasts for tone. In many Bantu languages (see, e.g., Philippson 1998), noun stems also have only one (underlying) High tone per stem, not one on every syllable, even though High tones can be found contrastively on all syllables of the stem. ${ }^{14}$ These points are illustrated in the Jita data below:

12 As these authors make clear, it can be quite confusing to read through the literature on Bantu accent because the theoretical definition of accent and the tone systems motivating accentual formalisms have changed so much and so rapidly. Frequently the same authors writing on the same languages have changed their minds about whether the tone system of the language should be analyzed as accentual. As a result, when reading papers on Bantu accent, it should be borne in mind that a language is being characterized as "accentual" based on the theory of accentual representation prevailing at the time, rather than on some atheoretical conception of pitch-accent.

In some Bantu languages, the surface High tones are realized in an alternating pattern reminiscent of bounded stress systems. Work like Bickmore (1995), de Lacy (2002) and Pulleyblank (1983) has argued for a metrical (accentual) analysis of these tone patterns. As these analyses assume a different definition of accent from the one adopted in this paper, they are not considered in this survey of the accentual properties of Bantu tone realization. The interested reader should consult the works just cited for further discussion. In the data in the remainder of this paper, acute accent indicates High tone and Low tone is unmarked. 
(19) Jita High tone culminativity in lexical tone contrasts (Downing 1996)

(a) Verbs (infinitive form is shown; oku- is the infinitive prefix)

$\begin{array}{llll}\begin{array}{l}\text { High-toned stems } \\ \text { oku-lyá }\end{array} & \text { 'to eat' } & \begin{array}{l}\text { Low-toned stems } \\ \text { oku-sya }\end{array} & \text { 'to grind' } \\ \text { oku- } \square \text { óna } & \text { 'to see' } & \text { oku- } \square \text { uma } & \text { 'to hit' } \\ \text { oku-í:ga } & \text { 'to look for' } & \text { oku-i:ga } & \text { 'to pass a test' }\end{array}$

(b) Nouns (stem follows hyphen)

$\begin{array}{llll}\text { omu-gási } & \text { 'woman' } & \text { omu-sa:ni } & \text { 'friend' } \\ \text { omu-tu:ngá } & \text { 'rich person' } & & \\ \text { ji:-ng'okóra } & \text { 'knees' } & \text { omu-lamusi } & \text { 'judge' } \\ \text { li-dariná } & \text { 'tangerine' } & & \end{array}$

Most Bantu languages appear to be like Jita, imperfectly culminative since they preserve a contrast between stems which have a High tone and those which are toneless. However, some Bantu languages have taken a step further towards having an accentual system in that all words have a single High tone, consistently assigned to a limited number of positions in the word. For example, Odden (1988) shows that in Hibena, every noun must have a High tone, on either the penult or the pre-stem vowel, and most verb forms require a High tone on the penult:

(20) Hibena (Odden 1988; p 236, figs (19) and (20)

$\begin{array}{ll}\text { (a) Nouns } & \\ \text { mú-goosi } & \text { 'man', } \\ \text { hí-fuva } & \text { 'chest' } \\ \text { mu-guúnda } & \text { 'field' } \\ \text { lu-fwíli } & \text { 'hair' } \\ \text { li-fulúha } & \text { 'cloud' }\end{array}$

(b) Verbs

kwaamíle ndi-líma ndaa-limága 'put to pasture' (subjunctive) ndaa-limiíge 'I will cultivate' (near-future) 'I used to cultivate' 'I was cultivating' ndihaa-limíle 'I cultivated' (intermediate past) ndaa-limíle 'I cultivated' (far past) hu-limíla 'to cultivate for'

Other languages like Hibena are discussed in Odden's $(1988,1999)$ critical overviews of what he calls "predictable" tone systems in Bantu languages. 
Besides these lexical culminativity effects, many Bantu languages also have processes eliminating sequences of High tones. One of the most common of these is Meeussen's Rule (Goldsmith 1984, Clements \& Goldsmith 1984), a process which deletes all but one High tone in a sequence. ${ }^{15}$ The Jita data in (21) illustrates this process. Three consecutive syllables - the Yesterday Past prefix /má-/, the object prefix immediately preceding the stem, and the verb stem-initial syllable - arguably contain High tones in the input. (See Downing (1996) for a detailed analysis of the Jita tone system.) However, only one High tone, the one on the object prefix, surfaces (and shifts one syllable to the right unless the following syllable is phrase-final):

(21) Jita examples of Meeussen's Rule (Downing 1996, p 220) - High-toned input vowels are underlined; '[' indicates the stem edge

(a) a:-ma-gá-[lya

(b) a:-ma-

(c) a:-má-ku- $\underline{\text { cósorera }}$

(d) a:-ma-ci- $[$ sí:ndika 's/he ate them (class 6)'

's/he saw him (class 2)'

's/he visited you'

's/he pushed us'

As Clements \& Goldsmith (1984) and Philippson (1998) argue, Meeussen's Rule is one of the important synchronic and diachronic processes lending an accentual character to Bantu tone systems, because it results in culminative prominence of High tone.

Another common process resulting in culminativity is tone shift. The Jita data in (22) provide examples of this process. Notice that an input High tone is systematically realized one syllable to the right of its input sponsor unless the sponsor is in the penult or final syllable.

(22) Jita tone shift (High-toned input vowels are underlined; '[' indicates the stem edge)
(a) oku-[ [■óna
'to see'
(b) oku-[Пonána
'to see each other'
(c) oku-[ロuma
'to hit'

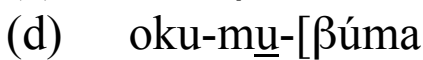
'to hit him/her (class 1)'

15 As Cassimjee (1998), Cassimjee \& Kisseberth (1998) and Kisseberth \& Odden (2003) argue, Meeussen's Rule is one of a family of processes found in Bantu languages which are motivated by the Obligatory Contour Principle (OCP). The interested reader can consult these works for discussion and exemplification. See, too, work like Goldsmith (1984) and Bickmore (1992) for analyses casting Meeussen's Rule in terms of accent clash resolution. 
(e) oku-[fwá $\quad$ 'to die' $\quad \begin{aligned} & \text { kumugera 'by the river' } \\ & \text { oku-[fwa kúmugera }\end{aligned}$
'to die by the river'

As Kenstowicz (1993), Cassimjee \& Kisseberth (1998) and Kisseberth \& Odden (2003) show, tone shift is clearly related to the assimilatory process of tone spread. What is puzzling is why the High tone should delink from its sponsor syllable, since other types of feature assimilation do not typically involve such delinking. Kenstowicz (1993) argues that delinking is best explained if High tone in Jita is analogous to stress accent. Then delinking can be seen as a process leading to High tone culminativity. Since it eliminates the sequence of High tones on adjacent syllables derived by tone spread, it makes one syllable of the string originally involved in tone spread more prominent than the others. ${ }^{16}$

\subsubsection{Positional restrictions on tone realization}

As noted in Section 1, main stress cross-linguistically tends to occur on syllables at the edge of a stem or word. In many Bantu languages, we find that tones are extremely mobile, spreading or shifting to positions several syllables from their sponsor to syllables at word or stem edges. The target for spread or shift in many languages is the penult syllable (see, e.g., Philippson 1998). For example, Cassimjee \& Kisseberth (2000) show that in Giryama, if a verb word contains a single High tone, it surfaces on the (stressed) penult syllable, no matter which syllable in the word sponsors the High tone:

(23) Giryama High tone shift to penult (Cassimjee \& Kisseberth 2000, fig (4)); High-toned sponsor vowels are underlined

$\begin{array}{llll}\text { (a) ku-zi:ra } & \text { 'to hate' } & \text { a-na-zí:ra } & \text { 's/he hates' } \\ \text { (b) ku-lamu:sa } & \text { 'to greet' } & \text { a-na-lamú:sa } & \text { 's/he greets' } \\ \text { (c) ku-kalangí:ra } & \text { 'to fry for' } & \\ & \text { ku-kạlangirá:na } & \text { 'to fry for each other' } \\ \text { (d) ni-ki-rí:ma } & \text { 'if I cultivate' ni-ki-lamú:sa } & \text { 'if I greet' } \\ \text { (e) hu-dza-lamusá:na } & \text { 'we have greeted each other' } & \end{array}$

As Cassimjee \& Kisseberth (1998), Odden (1999) and Kisseberth \& Odden (2003) argue, one reason the penult is a likely target of tone spread or shift is that High tone realization is subject to the metrical principle of Nonfinality. If a High tone spreads or shifts as far to the right edge of the word as possible,

16 I am abstracting away from the theoretical details of Kenstowicz's (1993) analysis. The interested reader can consult Kenstowicz (1993) and Cassimjee \& Kisseberth (1998) for discussion of how delinking can be formalized in terms of metrical/prosodic constituency. 
avoiding the final syllable, then the (rightmost or only) High tone will surface on the penult.

The penult is also a common position for main stress in stress-accent systems, often favored over the final syllable. Hyman (1977) argues that there is a perceptual reason for this tendency. The pitch fall that is one of the most salient perceptual cues to stress-accent is more noticeable if it is realized over two syllables (e.g., the penult and final) than only on the final syllable. The tendency for High tones to be realized on the penult and avoid final syllables in Bantu languages plausibly has a similar motivation: it allows High tones to be realized in a more perceptually salient position.

Cassimjee \& Kisseberth (1998) and Kisseberth \& Odden (2003) argue that the principle of Nonfinality unifies other processes found in Bantu languages which result in a High tone on the penult instead of the expected final syllable. For example, as shown in (21) and (22) above, High tones regularly shift one syllable rightward from their sponsors in Jita. A regular exception, shown in (21a) and (22a), is that they never shift from the penult to a phrase-final syllable. (See Downing (1996) for detailed discussion.) And in languages like High Runyankore High tones sponsored by final syllables shift to the penult phrasefinally (Poletto 1998). All of these processes motivated by Nonfinality reinforce the prominence of the penult syllable, as they converge on making it the target of High tone realization. ${ }^{17}$

Besides the penult, the stem-initial syllable is also a common target for High tone shift or spread. For example, in Giryama, if the verb word contains two High tones, the rightmost one shifts to the penult (see (23), above) while the leftmost shifts to the initial syllable:

(24) Giryama High tone shift to stem-initial syllable and penult (Cassimjee \& Kisseberth 2000, fig. (18)); '[' indicates the left stem edge

(a) ku-[tsagatsá:ga 'to break, damage' a-na-[tságatsá:ga 's/he breaks'

(b) ku-[kubbaliyá:na 'to agree' a-na-[kúbaliyá:na 's/he agrees'

(c) ku-[tsundzulú:ka 'to become sober' a-na-[tsúndzulú:ka 's/he becomes sober'

Other examples of shift of some High tones to the stem-initial syllable are found in Digo (Kisseberth 1984) and Chizigula (Kenstowicz \& Kisseberth 1990, Kisseberth 1992).

17 Another frequent Nonfinality effect is found in languages like Bondei where High tones are deleted phrase-finally. This process has what might be called an "anti-accentual effect" since it eliminates High tones altogether from the stem. 


\subsubsection{The interaction of tone and stress-accent}

A final property of Bantu tone languages which lends them an accentual character is the interaction of tone with (stress-)accent. As shown above, the penult is the most common locus for stress-accent in Bantu languages. It is no accident, then that, as Kisseberth \& Odden (2003) and Philippson (1998) note, one finds a number of "penult effects" on tone in a number of Bantu languages. First, as illustrated by the Giryama data in (23) and (24), in at least some of the languages where High tones shift to the penult, the penult also has stress-accent. (This is indicated by length on the penult in Giryama.) As Philippson (1998) argues, one motivation for High tone shift to the penult is that the High tone is "attracted" to the stressed syllable. As a result, pitch change, a main correlate of stress-accent, is realized on the same syllable as other correlates of stress-accent (notably, duration).

Another penult effect on tone is found in Chaga (McHugh 1990, 1999). Chaga has a Super-High tone which results from raising High tones which occur on the phrase penult syllable (if it is not followed by a High-toned syllable in the phrase). Low tones on the phrase-penult syllable are also raised in the same context. As McHugh $(1990,1999)$ plausibly argues, tone raising is best explained as the realization of an accent on the phrase penult syllable.

Paradoxically, a final common penult effect is for High tones to target the syllable before the penult (i.e., the antepenult). Perhaps the most well-known example of this is found in Nguni languages like Xhosa. As shown in the data below, the penult is lengthened under stress-accent while High tones regularly spread or shift to the antepenultimate syllable:

(25) Xhosa antepenult shift (Cassimjee \& Kisseberth (1998), p 77, fig (61));

High-toned sponsor vowels are underlined

(a) ba-ya-chukúmi:sa

'they provoke'

(b) ba-ya-móne:la

'they are jealous'

(c) ba-ya-xóle:la

'they forgive'

(d) ba-ya-qononóndi:sa

'they emphasize'

Cassimjee \& Kisseberth (1998) argue that High tones in Xhosa (and other languages like this) target the antepenult instead of shifting further right (to the penult) to avoid the syllable which is prominent for stress-accent. More research is necessary to understand why High tones are attracted to the stressed syllable in some languages, while High tone and stress-accent remain independent in others. Independence of tone and stress are especially intriguing in languages like Xhosa where both are positionally conditioned. 
As we can see, several factors converge to make the stem-initial syllable and the penult more prominent in Bantu languages. The stem-initial syllable is the locus of tone and vowel contrast in verb stems and a target of tone shift or spread, and it has stress-accent in Western Lingala. The penult has stress-accent in many Bantu languages and is a frequent site of High tone realization, either through shift or spread or to avoid a High tone on the phrase-final syllable. And the penult is the locus of tone raising in languages like Chaga. All of these properties lend credence to traditional claims (see e.g. Werner 1919) that the initial syllable and the penult are accented in Bantu languages.

\section{Conclusion}

As we have seen, African languages exhibit a rich variety of accentual systems. Many have familiar stress-accent systems, with the penult and/or initial syllable being especially common loci for stress-accent. These results confirm Hyman's (1977) finding that penult and initial positions are most likely to be assigned main stress, cross-linguistically. Many of the languages also have asymmetries in feature distribution or positional restrictions on tone realization which I have argued are best considered accentual in nature. The variety of accentual systems we find in African languages, indeed usefully highlights how elusive the notions of prominence and accent are, so that this survey leaves us with a number of questions. How is stress-accent phonetically realized in languages where vowel length and tone are contrastive? How can one reliably distinguish the impression of prominence given by vowel length and tone from stress-accent? How are apparently competing positional prominence asymmetries (like positionally restricted vowel length and positionally restricted tone) coordinated (or distinguished)? And do languages with featural distribution asymmetries within a bimoraic or bisyllabic constituent have other correlates of stress-accent within that same domain? It is hoped that this paper will stimulate more research on accent in African (and other) languages, and especially of the phonetic correlates of accent, to help resolve questions like these on the nature of accent and prominence systems. 


\section{References}

Abdel-Massih, Ernest T. 1971. A Reference Grammar of Tamazight (Middle Atlas Berber). University of Michigan, Ann Arbor: Center for Near Eastern and North African Studies.

Abu-Absi, Samir. 1995. Chadian Arabic. Munich: LINCOM EUROPA.

Akinlabi, Akinbiyi \& Eno Urua. 2002. Foot structure in the Ibibio verb. JALL 23, 119-160.

Amha, Azeb. 1996. Tone-accent and prosodic domains in Wolaitta. SAL 25, 111-138.

Angoujard, Jean-Pierre. 1990. Metrical Structure of Arabic. Dordrecht: Foris.

Anyanwu, Rose-Juliet. 2002. On the manifestation of stress in African languages. In Ulrike

Gut \& Dafydd Gibbon, eds. Proceedings, Typology of African Prosodic Systems.

Bielefeld Occasional Papers in Typology 1, 149-157.

Applegate, Joseph R. 1958. An Outline of the Structure of Shilha. ACLS Program in Oriental Languages, Publications Series B - Aids - No. 11. New York: ACLS.

Ashton, E.O. 1969. Swahili Grammar. London: Longmans.

Beaujard, Philippe. 1998. Dictionnaire Malgache-Français. Paris: L'Harmattan.

Bender, Lionel M. 2000. Nilo-Saharan. In Heine \& Nurse, eds., 43-73.

Bendor-Samuel, John, ed. 1989. The Niger-Congo Languages. Lanham, MD: University Press of America.

Bennett, Patrick R. 1978. The role of stress and intonation in early Proto-Bantu. ms. University of Wisconsin. (Paper presented at the $9^{\text {th }}$ Annual Conference on African Linguistics, Michigan State University.)

Bickmore, Lee S. 1992. Multiple phonemic stress levels in Kinyambo. Phonology 9, 155-198.

Bickmore, Lee S. 1995. Tone and stress in Lamba. Phonology 12, 307-341.

Bickmore, Lee. 2001. Downstep and Fusion in Namwanga. Phonology 17.3, 297-333.

Boyd, Raymond. 1989. Adamawa-Ubangi. In Bendor-Samuel, ed.

Cann, Gaston. 1976. La langue Mò:ré. Paris: SELAF.

Carlson, Robert. 1994. A grammar of Supyire. Berlin: Mouton de Gruyter.

Cassimjee, Farida. 1998. IsiXhosa Tonology: an Optimal Domains Theory Analysis. LINCOM Studies in African Linguistics 29. Munich: LINCOM EUROPA.

Cassimjee, Farida \& Charles W. Kisseberth. 1998. Optimality Domains Theory and Bantu tonology: a case study from Isixhosa and Shingazidja. In Larry M. Hyman \& Charles W. Kisseberth, eds. Theoretical Aspects of Bantu Tone. Stanford, Calif.: CSLI, 33-132.

Cassimjee, Farida \& Charles W. Kisseberth. 2000. Opaque and depressed: Giryama tonology. Paper presented at the Tone Symposium, Tromsø, Norway, June 2000.

Clements, G.N. \& John Goldsmith. 1984. Introduction. Autosegmental Studies in Bantu Tone. Dordrecht: Foris, 1-17.

Cook, Thomas L. 1985. An integrated phonology of Efik. Volume I. University of Leiden.

deLacy, Paul. 2002. The interaction of tone and stress in Optimality Theory. Phonology 19, 132.

Doke, C.M. 1954. The Southern Bantu Languages. London: Oxford University Press for the International African Institute.

Downing, Laura J. 1996. The Tonal Phonology of Jita. LINCOM Studies in African Linguistics 05. Munich: LINCOM EUROPA. 
Dresel, Linda. 1977. An Experimental Study of Hausa Tone. PhD dissertation, Indiana University.

Dwyer, David. 1989. Mande. In Bendor-Samuel, ed.

Ethnologue. 2000. Edited by Barbara F. Grimes. Consulting Editors, Richard S. Pittman \& Joseph E. Grimes. Internet version, http://www.sil.org/ethnologue/

Faraclas, Nicholas G. 1989. Cross-River. In Bendor-Samuel, ed.

Felberg, Knut. 1996. Nyakyusa-English-Swahili and English-Nyakyusa Dictionary. Dar es Salaam, Tanzania: Mkuki na Nyota Publishers.

Fischer, Wolfdietrich \& Otto Jastrow, eds. 1980. Handbuch der Arabischen Dialekte. Wiesbaden: O. Harrassowitz.

Gerhardt, Ludwig. 1989. Kainji and Platoid. In Bendor-Samuel, ed.

Gilley, Leoma. 2003. The feature of stress in Nilotic. In Rose-Juliet Anyanwu (ed.), Stress and Tone - the African Experience. Frankfurther Afrikanistische Blätter 15. Köln: Rüdiger Köppe Verlag, 99-120.

Goldsmith, John. 1984. Meeussen's rule. In M. Aronoff \& R.T. Oehrle, eds. Language Sound Structure. Cambridge, Mass.: MIT Press, 245-259.

Güldemann, Tom \& Rainer Vossen. 2000. Khoisan. In Heine \& Nurse, eds., 99-122.

Guthrie, Malcolm \& John F. Carrington. 1988. Lingala Grammar and Dictionary. London: Baptist Missionary Society.

Haacke, Wilfrid H. 1999. The tonology of Khoekhoe (Nama/Damara). Köln: Rüdiger Köppe Verlag.

Harrell, Richard. 1957. The Phonology of Colloquial Egyptian Arabic. ACLS Program in Oriental Studies, Publications Series B - Aids - No. 9. New York: ACLS.

Harrell, Richard. 1962. A Short Reference Grammar of Moroccan Arabic. DC: Georgetown University Press.

Harris, John. 2004. Release the captive coda: the foot as a domain of phonetic interpretation. In John Local, Richard Ogden \& Rosalind Temple (eds.), Phonetic Interpretation: Papers in Laboratory Phonology 6. Cambridge: Cambridge University Press, 103-129.

Hayes, Bruce. 1995. Metrical Stress Theory: Principles and Case Studies. Chicago: University of Chicago Press.

Hayward, Richard J. 2000. Afroasiatic. In Heine \& Nurse, 74-98.

Heath, Jeffrey. 1999. A Grammar of Koyraboro (Koroboro) Senni. The Songhay of Gao, Mali. Berlin: Walter de Gruyter.

Heine, Bernd \& Derek Nurse. 2000. Introduction. In Heine \& Nurse, eds., 1-10.

Heine, Bernd \& Derek Nurse, eds. 2000. African Languages: An Introduction. Cambridge: Cambridge University Press.

Hetzron, Robert, ed.. 1997. The Semitic Languages. London: Routledge.

Horton, A.E. 1949. A Grammar of Luvale. Johannesburg: Witwatersrand University.

Hudson, R. A. 1973. Syllables, moras and accents in Beja. Journal of Linguistics 9, 53-63.

Hyman, Larry M. 1977. On the nature of linguistic stress. In L.M. Hyman, ed. Studies in Stress and Accent. SCOPIL 4, 37-82.

Hyman, Larry M. 1978. Tone and/or accent. In Donna Jo Napoli, ed. Elements of Tone, Stress, and Intonation. Washington, DC: Georgetown University Press, 1-20.

Hyman, Larry M. 1981. Tonal accent in Somali. SAL 12, 169-203.

Hyman, Larry M. 1989. Accent in Bantu: an appraisal. Studies in the Linguistic Sciences 19, 115-134. 
Hyman, Larry M. 1990. Non-exhaustive syllabification: evidence from Nigeria and Cameroon. CLS 26 (2), 175-195.

Hyman, Larry M. 2000. Cyclicity and templatic morphology in the Basaa verb stem. Paper presented at the $2^{\text {nd }}$ Round Table in Phonology of the GDR 1954, Bordeaux, June 8, 2000 .

Hyman, Larry M. \& Sharon Inkelas. 1997. Emergent templates: the unusual case of Tiene. In Viola Miglio \& Bruce Morén, eds. University of Maryland WPL 5, 92-116.

Innes, Gordon. 1966. An Introduction to Grebo. SOAS. Printed by The Hague: Mouton.

Johnson, Lawrence. 1976. Devoicing, tone, and stress in Runyankore. SCOPIL 3, 207-216.

Ka, Omar. 1988. Wolof Phonology and Morphology: a Non-linear Approach. PhD dissertation. University of Illinois at Urbana-Champaign.

Kaye, Alan S., ed. \& Daniels, Peter T., technical advisor. 1997. Phonologies of Asia and Africa: including the Caucasus. Winona Lake, Ind.: Eisenbrauns.

Keenan, Edward L. \& Maria Polinsky. 1998. Malagasy (Austronesian). In Andrew Spencer \& Arnold M. Zwicky, eds. The Handbook of Morphology. Oxford: Blackwell, 563-623.

Kenstowicz, Michael. 1993. Evidence for metrical constituency. In Kenneth Hale \& Samuel Jay Keyser, eds. The View from Building 20: Essays in Linguistics in honor of Sylvain Bromberger. Cambridge, Mass.: The MIT Press, 257-273.

Kenstowicz, Michael \& Charles W. Kisseberth. 1979. Generative Phonology: Description and Theory. New York: Academic Press.

Kenstowicz, Michael \& Charles W. Kisseberth. 1990. Chizigula tonology: the word and beyond. In Sharon Inkelas \& Draga Zec, eds. The Phonology-Syntax Connection. Chicago: The University of Chicago Press, 163-194.

Kisseberth, Charles W. 1984. Digo tonology. In G.N. Clements \& John Goldsmith, eds. Autosegmental Studies in Bantu Tone. Dordrecht: Foris, 105-182.

Kisseberth, Charles W. 1992. Metrical structure in Zigula tonology. Derek F. Gowlett, ed. African Linguistic Contributions. Pretoria: Via Afrika Limited, 227-259.

Kisseberth, Charles W. 2000. The phonology-syntax interface: Chimwiini revisited. ms., Tel Aviv University.

Kisseberth, Charles W. \& Mohammed I. Abasheikh. 1974. Vowel length in ChiMwi:ni - a case study of the role of grammar in phonology. In A. Bruck, A. Fox \& M. W. La Galy, eds. CLS Papers from the Parasession on Natural Phonology, 193-209.

Kisseberth, Charles W. \& David Odden. 2003. Tone. In Derek Nurse \& Gérard Philippson, eds. The Bantu Languages. London: Routledge, 59-70.

Leben, William R. 2002. Tonal feet. In Ulrike Gut \& Dafydd Gibbon, eds. Proceedings, Typology of African Prosodic Systems. Bielefeld Occasional Papers in Typology 1, 2740.

Leger, Rudolf. 1994. Eine Grammatik der Kwami-Sprache (Nordost-nigeria). Köln: Rüdiger Köppe Verlag.

Leslau, Wolf. 1995. Reference Grammar of Amharic. Wiesbaden: Harrassowitz.

Liphola, Marcelino M. 2001. Aspects of Phonology and Morphology of ShiMakonde. Ph.D. dissertation, The Ohio State University.

Marchese, Lynell. 1989. Kru. In Bendor-Samuel, ed.

McCarthy, John. 1979. Formal Problems in Semitic Phonology and Morphology. PhD dissertation, MIT. 
McCawley, James. 1970. Some tonal systems that come close to being pitch accent systems but don't quite make it. CLS 6, 526-532.

McCawley, James. 1978. What is a tone language? In V. Fromkin, ed. Tone: A linguistic survey. New York: Academic Press, 113-131.

McHugh, Brian. 1990. The phrasal cycle in Kivunjo Chaga tonology. In Sharon Inkelas \& Draga Zec, eds. The Phonology-Syntax Connection. Chicago: The University of Chicago Press, 217-242.

McHugh, Brian. 1999. Cyclicity in the Phrasal Phonology of Kivunjo Chaga. LINCOM Studies in African Linguistics 03. Munich: LINCOM EUROPA.

Miller-Ockhuizen, Amanda. 1998. Towards a Unified Decompositional Analysis of Khoisan Lexical Tone. In Mathias Schladt, ed. Language, Identity and Conceptualization among the Khoisan. (Research in Khoisan Studies 15). Köln: Rüdiger Köppe, 217-244.

Miller-Ockhuizen, Amanda. 1999. C-V coarticulations and complex consonants: New evidence for the ordering of place gestures in click consonants. In O. Fujimura, B. D. Joseph \& B. Palek, eds. Proceedings of LP '98. Prague: Charles University, 301-330.

Miller-Ockhuizen, Amanda. 2001a. Contrastive vowel-length and variable weight reduplicative templates in Ju|'hoansi. In A. Bell \& P. Washburn, eds. Cornell Working Papers in Linguistics 18, 104-125.

Miller-Ockhuizen, Amanda. 2001b. Grounding Ju|'hoansi Phonotactics: The Phonetics of the Guttural OCP and other Acoustic Modulations. Ph.D. dissertation. The Ohio State University.

Mitchell, T. F. 1993. Pronouncing Arabic 2. Oxford: Clarendon Press.

Mous, Maarten. 1993. A Grammar of Iraqw. Cushitic Studies 9. Hamburg: Helmut Buske.

Mutaka, Ngessimo M. 1994. The Lexical Tonology of Kinande. LINCOM Studies in African Linguistics 01. Munich: LINCOM EUROPA.

Mutaka, Ngessimo M. \& Larry M. Hyman. 1990. Syllables and morpheme integrity in Kinande reduplication. Phonology 7, 73-119.

Naden, Tony. 1989. Gur. In Bendor-Samuel, ed.

Newman, Paul. 1986. Contour tones as phonemic primes in Grebo. In Koen Bogers, Harry van der Hulst \& Maarten Mous, eds. The Phonological Representation of Suprasegmentals. PALL 4. Dordrecht: Foris, 175-193.

Newman, Paul. 2000. The Hausa Language: An Encyclopedic Reference Grammar. New Haven: Yale University Press.

Niang, Mamadou O. 1997. Constraints on Pulaar Phonology. Lanham, MD: University Press of America.

Nicolaï, Robert \& Petr Zima. 1997. Songhay. Munich: LINCOM EUROPA..

Noonan, Michael. 1992. A Grammar of Lango. Berlin: Mouton de Gruyter.

Odden, David. 1988. Predictable tone systems in Bantu. In Harry van der Hulst \& Norval Smith, eds. Autosegmental Studies on Pitch Accent. Dordrecht: Foris, 225-251.

Odden, David. 1995. Tone: African Languages. In John A. Goldsmith, ed. The Handbook of Phonological Theory. Cambridge, Mass.: Blackwell, 444-475.

Odden, David. 1999. Typological issues in tone and stress in Bantu. In Shigeki Kaji, ed. Proceedings of the Symposium on Cross-Linguistic Studies of Tonal Phenomena: Tonogenesis, Typology, and Related Topics. Tokyo: ILCAA, 187-215.

Olawsky, Knut J. 1999. Aspects of Dagbani Grammar. Munich: LINCOM EUROPA.

Owens, Jonathan. 1993. A Grammar of Nigerian Arabic. Wiesbaden: Harrassowitz. 
Philippson, Gérard. 1998. Tone reduction vs. metrical attraction in the evolution of Eastern Bantu tone systems. In Larry M. Hyman \& Charles W. Kisseberth, eds. Theoretical Aspects of Bantu Tone. Stanford, Calif.: CSLI, 315-329.

Poletto, Robert E. 1998. Topics in Runyankore Phonology. PhD dissertation, The Ohio State University.

Pulleyblank, Douglas. 1983. Accent in Kimatuumbi. In Jonathan Kaye, Hilda Koopman, Dominique Sportiche \& André Dugas, eds. Current Approaches to African Linguistics (vol. 2). Dordrecht: Foris Publications, 195-215.

Rennison, John R. 1997. Koromfe. London: Routledge.

Richter, Renate. 1987. Lehrbuch der amharischen Sprache. Leipzig: VEB Verlag.

Ruhlen, Merritt. 1975, 1976. A Guide to the Languages of the World. [self-published].

Sapir, J. David. 1965. A Grammar of Diola-Fogny. Cambridge: Cambridge University Press.

Sasse, Hans-Jürgen. 1981. Die kuschitischen Sprachen. In Bernd Heine, Thilo C. Schadeberg \& Ekkehard Wolf, eds. Die Sprachen Afrikas. Hamburg: Helmut Buske Verlag, 187215.

Selkirk, Elisabeth. 1986. On derived domains in sentence phonology. Phonology Yearbook 3, 371-405.

Soukka, Maria. 2000. A Descriptive Grammar of Noon: A Cangin Language of Senegal. Munich: LINCOM EUROPA.

Taylor, Charles. 1985. Nkore-Kiga. London: Croom Helm.

Traill, Anthony. 1985. Phonetic and Phonological Studies of !Xóõ Bushman. Hamburg: Helmut Buske Verlag.

Tucker, A.N. 1993. A Grammar of Kenya Luo (Dholuo). Ed. by C. A. Creider, with the collaboration of T. Okelo Odongo, E.D. Jakeyo Ang'ina \& J. N. Olum Oludhe. Köln: Rüdiger Köppe Verlag.

Tucker, A.N. \& P.E. Hackett. 1959. Le groupe linguistique Zande. Tervuren: Annales du Musée Royal du Congo Belge, Série in- $8^{\circ}$, Sciences de 1'Homme, Linguistique, vol. 22.

Urua, Eno-Abasi E. 1999. Length and syllable weight in Ibibio. SAL 28, 241-266.

Van der Hulst, Harry \& Norval Smith. 1988. Introduction. Autosegmental Studies on Pitch Accent. Dordrecht: Foris, ix-xxiv.

Vydrine, Valentin. to appear. Areal and genetic features in West Mande and Mani-Bandama (East Mande) phonology: In what sense did Mande languages evolve? JWAL.

Welmers, William E. 1973. African Language Structures. Berkeley, Calif.: University of California Press.

Werner, Alice. 1919. Introductory Sketch of the Bantu Languages. London: Kegan, Paul, Trench, Trubner and Co.

Williamson, Kay. 1978. Consonant distribution in Ijo. In Mohammad Ali Jazayery et al, eds. Linguistic and Literary Studies in Honor of Archibald A. Hill, vol. 3. The Hague: Mouton, 341-353.

Williamson, Kay \& Roger Blench. 2000. Niger-Congo. In Heine \& Nurse, eds., 11-42.

Wolff, H. Ekkehard. 1993. Referenzgrammatik des Hausa. Münster: LIT Verlag. 